УДК 504.06

(C) 2014

Санжаревська О. І., аспірант

(Науковий керівник - кандидат економічних наук М. С. Самойлік)

Полтавський національний технічний університет ім. Юрія Кондратюка

\title{
АНАЛІЗ ВПЛИВУ ГАЗОКОНДЕНСАТНИХ ЗАБРУДНЕНЬ НА СТАН ГРУНТІВ ПОЛТАВЩИНИ
}

\section{Рецензен - доктор сільськогосподарських наук, професор П. В. Писаренко}

\begin{abstract}
У статті досліджено фізико-хімічні показники трунту, забрудненого нафтогазоконденсатною сумішшю різної давності: 6 місящів, 12 місяџів, 36 місяців та проведено його порівняння з грунтом, незабрудненим нафтопродуктами на прикладі Полтавської області. Визначено головні негативні наслідки впливу газоконденсату на трунтові екосистеми ц̌ зроблені висновки про придатність трунту для сільськогосподарського використання та можливі шляхи його покращання. Практична значимість роботи полягає в розробці концептуальних засад поліпшення стану грунтів Полтавського регіону, зокрема за рахунок фітомеліоративних заходів; обтрунтуванні иляхи локалізації газоконденсатних виливів $і$ відновлення трунтів після газоконденсатних забруднень.
\end{abstract}

Ключові слова: трунт, газоконденсатна суміш, нафтогазопроводи, фізико-хімічні показники, фіторемедіація.

Постановка проблеми. У сучасних умовах внаслідок зростаючого техногенного забруднення довкілля особливого значення набуває проблема забезпечення екологічно безпечних умов існування суспільства. Масштабна антропогенна трансформація природних екосистем супроводжується зменшенням запасів природних ресурсів, знищенням багатьох біологічних видів, подальшим погіршенням екологічної ситуації й, як наслідок, - погіршенням здоров'я населення. У той же час територія України насичена потенційно небезпечними технічними об'єктами й системами, окремі їі регіони мають техногенно напружений і навіть кризовий стан навколишнього середовища.

У державному балансі України налічується 323 родовища запасів нафти, газу і газового конденсату. Обсяг щорічного видобутку вуглеводнів за останні роки у середньому становив 4 млн т нафти 3 конденсатом і 18 млрд м ${ }^{3}$ газу, що дорівнювало, відповідно, $10 \%$ і $20 \%$ обсягів цих видів сировини, які щороку споживає країна [11]. Сучасним пріоритетним елементом народного господарства України вважається нафтогазовидобувний комплекс, який перетворився на один iз найнебезпечніших джерел забруднення біосфери.
В Україні промислово розробляються близько 200 родовищ, що є базою нафтогазової промисловості. На сьогодні в промисловій експлуатації знаходиться 47 родовищ, експлуатуються 2 газосховища. Перспективним із видобутку нафти i газу вважається Донецько-Придніпровський регіон, в якому зосереджено близько $85 \%$ ресурсів вуглеводнів країни. Так само відкрито газові родовища в Карпатах, розширюються пошуки нафти на Чорноморському шельфі. Водночас виникає проблема забруднення навколишнього середовища газоконденсатом у процесі виробництва, транспортування, а також у результаті аварійних ситуацій, пов'язаних із механічним пошкодженням трубопроводів, зношуванням технічного обладнання об'єкта, а також із несанкціонованими врізаннями в нафтогазопроводи 3 метою розкрадання [8]. Основною складовою, що зазнає найбільш негативного впливу від нафтогазової промисловості, є грунтовий покрив, який першим приймає на себе удар під час виникнення аварій чи розливів. Близько 70 \% території України займають сільськогосподарські угіддя, тому забруднення грунтів нафтою й газоконденсатом становлять загрозу для їі регіонів.

Аналіз останніх досліджень та публікацій, у яких започатковано розв'язання проблеми. Проблеми та наслідки впливу паливноенергетичного комплексу на складові довкілля, зокрема грунтові екосистеми, досліджувало чимало як вітчизняних, так і зарубіжних науковців. Останнім часом було опубліковано низку наукових праць, що стосуються проблеми розвитку нафтогазовидобувного комплексу; пропонуються підходи у вирішенні окремих екологічних проблем стосовно його експлуатації. Варто відмітити праці таких авторів як О. М. Алімова, О. I. Амоша, М. М. Ворончук, у яких висвітлюються загальні екологічні проблеми паливноенергетичного комплексу [1]; Ю. В. Макогона, Ященко Ю. П., Чилікіна А. І., Довжок Є. М., які розглядають дані проблеми в розрізі управління екологічною безпекою [7]. Також необхідно відзначити дослідження Плешакової Е. В., Мазло- 


\section{СТОРІНКА МОЛОДОГО ВЧЕНОГО}

вої Е. А., Шагарової Л. Б., які запропонували екологічні рішення зниження техногенного навантаження у нафтогазовому комплексі [10]. Водночас потребує глибшого дослідження питання щодо впливу нафтогазоконденсаних забруднень на грунти, зокрема обгрунтування методів відновлення забруднених грунтів залежно від тривалості й рівня забруднення.

Мета роботи: експериментальне визначення основних фізико-хімічних показників грунту 3 різним рівнем забруднення газоконденсатної суміші.

Завдання досліджень:

- провести фізико-хімічний аналіз грунту, відібраного в районах розливу газоконденсату різної давності: 6 місяців, 12 місяців, 36 місяців;

- здійснити порівняльний аналіз із грунтом незабрудненим нафтопродуктами та надати рекомендації щодо можливості відновлення забруднених грунтів.

Матеріали і методи досліджень. Проби грунту були відібрані відповідно до вимог стандартів [6] у районах найбільшого забруднення грунту нафтогазоконденсатною сумішшю внаслідок аварій, розливів і в результаті несанкціонованих врізок у трубопроводи впродовж різного періоду часу. Еталоном для порівняння став грунт 3 екологічно чистого куточка регіону Полтави, яким $\epsilon$ Дендропарк. Нами були експериментально визначені відповідно до методик [2-5] основні фізико-хімічні показники проб грунту. Під час його комплексного дослідження ми визначили гігроскопічну вологість грунту термостатичним i гідростатичним методами, вологоємність, густину, обмінну кислотність, вміст органічних речовин, $\mathrm{pH}$ водної витяжки, втрати маси в процесі прожарювання, вміст водорозчинних солей у водній витяжці грунту, визначили іiі макрокомпонентний склад; окрім того ми провели якісний аналіз водної витяжки грунту з метою виявлення токсичних домішок, а також кореляційний аналіз одержаних результатів.

Результати дослідження. Полтавська область розташована в центральній частині лісостепової зони України 3 помірно-континентальним кліматом. «Нафтовою» вона стала називатися, починаючи 3 1966 року, після створення об'єднання «Укрсхіднафта» - нафтового центру Полтавщини та окремих прилеглих до неї областей. Полтавський нафтогазовидобувний район включає 7 родовищ, розташованих на території Полтавської, Дніпропетровської та Сумської областей (Глинсько-Розбишівське, Решетняківське, Лиманське, Малосорочинське, Радченківське, Суходолівське, Сагайдацьке). Полтавському краю властива густа мережа трубопроводів, оскільки вона відноситься до Дніпровсько-Донецької нафтогазоносної області. Так, виробляючи 5 \% промислової продукції країни, Полтава виробляє разом із тим $20,5 \%$ нафти і газового конденсату й 34,8 \% природного газу країни.

Актуальною проблемою області $є$ значна засоленість грунтів: 226 тис. га орних земель із різним ступенем осланцювання (переважно на півдні області). Головною причиною цього виду деградації є викиди пластової води, застосування хімічних реагентів у процесі буріння, обслуговування свердловин та інтенсифікації видобутку. Наявність розвиненої промисловості підвищує ймовірність виникнення надзвичайних ситуацій. Згідно $з$ опублікованими даними відділу аналітичного контролю держуправління екоресурсів Полтавської області, на сьогодні вміст гумусу в грунтах області, починаючи $360-\mathrm{x}$ років минулого століття, зменшився на 0,2-0,6\%. Серед об'єктів промисловості найбільший негативний вплив на стан земельних угідь в області створюють підприємства нафтогазового комплексу - у ході будівництва та експлуатації газонафтових свердловин, трубопровідного транспорту та в разі пошкоджень трубопроводів (найчастіше навмисних із метою крадіжки газоконденсату) [9].

Об'єктом дослідження було обрано Полтавську область, а, точніше, Диканський район, оскільки йому притаманна досить густа мережа трубопроводів і за результатами досліджень українських вчених відноситься до помірно забрудненого району, який має ті ж екологічні проблеми, що і вся країна, але з певною специфікою. У ході роботи нами було відібрано чотири проби грунту у с. Лихачівка Диканського району Полтавської області: незабруднена, та три проби грунту в місцях розливу газоконденсату.

Результати експериментального дослідження грунту представлені у таблиці.

Результати досліджень показали, що нафтогазоконденсатні забруднення негативно впливають на фізико-хімічні, біологічні та іонообмінні показники грунту, поскільки зміни відбуваються за всіма показниками:

а) змінюється водно-сольовий баланс, що $\epsilon$ основною причиною засоленості грунтів;

б) зменшується гумусова частина органічних речовин грунту.

Можна спостерігати, що в разі забруднення грунтового покриву газоконденсатом $\mathrm{pH}$ зміщюється в лужну сторону. В забруднених пробах грунту відбувається зростання нітрат-іонів, що може спричинити потрапляння їх у водоносні горизонти. 
Основні фізико-хімічні показники чистих та забруднених проб трунту*

\begin{tabular}{|c|c|c|c|c|c|}
\hline Показник & $\begin{array}{c}\text { Проба № } 1 . \\
\text { Еталонний } \\
\text { грунт, } \\
\text { м. Полтава, } \\
\text { район } \\
\text { Дендропарку }\end{array}$ & $\begin{array}{c}\text { Проба № } 2 . \\
\text { Чистий грунт, } \\
\text { Диканський } \\
\text { район }\end{array}$ & $\begin{array}{c}\text { Проба № } 3 . \\
\text { с. Михайлів- } \\
\text { ка, } 6 \text { місяців } \\
\text { (сильне } \\
\text { забруд- } \\
\text { нення) }\end{array}$ & $\begin{array}{c}\text { Проба № } 4 . \\
\text { Парасо- } \\
\text { цький } \\
\text { Ліс, } \\
12 \text { місяців }\end{array}$ & $\begin{array}{c}\text { Проба № } 5 . \\
\text { с. Лихачівка, } \\
36 \text { місяців } \\
\text { (реультиваційні } \\
\text { роботи) }\end{array}$ \\
\hline $\begin{array}{c}\text { Визначення } \\
\text { вологості грунту } \\
\text { термостатичним } \\
\text { методом }\end{array}$ & $2,8 \%$ & $1,4 \%$ & $4,2 \%$ & $3,1 \%$ & $11,7 \%$ \\
\hline $\begin{array}{c}\text { Вміст кристаліза- } \\
\text { ційної води }\end{array}$ & $1,21 \%$ & $5,66 \%$ & $17,4 \%$ & $5,76 \%$ & $50,5 \%$ \\
\hline $\begin{array}{c}\text { Вміст органічних } \\
\text { речовин }\end{array}$ & $2,61 \%$ & $1,13 \%$ & $1,23 \%$ & $1,2 \%$ & $6,3 \%$ \\
\hline Вміст гумусу & $2,35 \%$ & $0,96 \%$ & $1,05 \%$ & $1,02 \%$ & $5,36 \%$ \\
\hline $\begin{array}{l}\text { Втрати маси в про- } \\
\text { цесі прожарюванні }\end{array}$ & $6,7 \%$ & $8,19 \%$ & $23,88 \%$ & $10,06 \%$ & $68,5 \%$ \\
\hline $\begin{array}{c}\text { Вміст мінеральної } \\
\text { частини грунту }\end{array}$ & $93,29 \%$ & $91,81 \%$ & $76,12 \%$ & $89,94 \%$ & $31,5 \%$ \\
\hline $\begin{array}{c}\text { Обмінна } \\
\text { кислотність }\end{array}$ & $\begin{array}{c}1,22 \text { мл/ } \\
0,12 \text { мекв }\end{array}$ & 1,4 мл & 5,33 мл & 1,9 мл & 3,44 мл \\
\hline $\mathrm{pH}$ & 7,81 & 7,6 & 8,40 & 8,55 & 6,85 \\
\hline $\begin{array}{c}\text { Загальний вміст } \\
\text { водорозчинних } \\
\text { солей }\end{array}$ & 108,3 мг/л & 119,03 мг/л & 184,29 мг/л & 188,1 мг/л & 407,91 мг/л \\
\hline $\begin{array}{c}\text { Загальний вміст } \\
\mathrm{HCO}_{3}{ }^{-}\end{array}$ & $\begin{array}{c}50,90 \text { мг/ } \\
0,835 \text { мекв }\end{array}$ & $\begin{array}{c}27,46 \text { мг/ } \\
0,451 \text { мекв }\end{array}$ & $\begin{array}{l}88,473 \text { мг/ } \\
1,45 \text { мекв }\end{array}$ & $\begin{array}{l}\text { 61,02 мг/ } \\
1,00 \text { мекв }\end{array}$ & $\begin{array}{c}48,8 \text { мг/ } \\
0,80 \text { мекв }\end{array}$ \\
\hline $\begin{array}{c}\text { Загальний вміст } \\
\text { CI }\end{array}$ & $\begin{array}{c}36,84 \text { мг/ } \\
0,549 \text { мекв }\end{array}$ & $\begin{array}{c}31,00 \text { мг/ } \\
0,455 \text { мекв }\end{array}$ & $\begin{array}{c}37,21 \mathrm{мг/} \\
0,555 \text { мекв }\end{array}$ & $\begin{array}{c}77,6 \text { мг/ } \\
1,14 \text { мекв }\end{array}$ & $\begin{array}{c}26,59 \text { мг/ } \\
0,392 \text { мекв }\end{array}$ \\
\hline $\begin{array}{c}\text { Загальний вміст } \\
\mathrm{Ca}^{2+}\end{array}$ & $\begin{array}{c}13,45 \text { мг/ } \\
0,671 \text { мекв }\end{array}$ & $\begin{array}{c}9,03 \text { мг/ } \\
0,451 \text { мекв }\end{array}$ & $\begin{array}{c}12,02 \mathrm{мг/} \\
0,599 \text { мекв }\end{array}$ & $\begin{array}{l}15,03 \text { мг/ } \\
0,75 \text { мекв }\end{array}$ & $\begin{array}{c}14,032 \text { мг/ } \\
0,7 \text { мекв }\end{array}$ \\
\hline $\begin{array}{c}\text { Загальний вміст } \\
\mathrm{Mg}^{2+}\end{array}$ & $\begin{array}{c}6,601 \text { мг/ } \\
0,5432 \text { мекв }\end{array}$ & $\begin{array}{l}3,65 \text { мг/ } \\
0,3 \text { мекв }\end{array}$ & $\begin{array}{c}11,54 \text { мг/ } \\
0,949 \text { мекв }\end{array}$ & $\begin{array}{l}8,51 \mathrm{мг/} \\
0,7 \text { мекв }\end{array}$ & $\begin{array}{l}13,37 \text { мг/ } \\
1,1 \text { мекв }\end{array}$ \\
\hline $\begin{array}{c}\text { Загальний вміст } \\
\mathrm{SO}_{4}^{2+}\end{array}$ & $\begin{array}{c}8,2 \mathrm{мг} / \\
0,1712 \text { мекв } \\
\end{array}$ & $\begin{array}{c}33,3 \text { мг/ } \\
0,695 \text { мекв }\end{array}$ & $\begin{array}{c}23,63 \text { мг/ } \\
0,493 \text { мекв }\end{array}$ & $\begin{array}{c}21,14 \text { мг/ } \\
0,441 \text { мекв }\end{array}$ & $\begin{array}{c}210,3 \text { мг/ } \\
4,4 \text { мекв }\end{array}$ \\
\hline $\begin{array}{c}\text { Загальний вміст } \\
\mathrm{Na}^{+}\end{array}$ & $\begin{array}{c}\text { 7,836 мг/ } \\
0,341 \text { мекв }\end{array}$ & $\begin{array}{c}37,79 \mathrm{мг} / \\
1,644 \text { мекв }\end{array}$ & $\begin{array}{l}11,423 \text { мг/ } \\
0,497 \text { мекв }\end{array}$ & $\begin{array}{c}4,8 \text { мг/ } \\
0,21 \text { мекв }\end{array}$ & $\begin{array}{c}94,95 \text { мг/ } \\
4,129 \text { мекв }\end{array}$ \\
\hline $\begin{array}{c}\text { Загальний вміст } \\
\mathrm{NO}_{3}{ }^{-}\end{array}$ & $\begin{array}{c}0,3 \text { мг/ } \\
0,005 \text { мекв }\end{array}$ & $\begin{array}{c}0,55 \text { мг/ } \\
0,0092 \text { мекв }\end{array}$ & $\begin{array}{c}1,2 \text { мг/ } \\
0,003 \text { мекв }\end{array}$ & $\begin{array}{c}1,25 \text { мг/ } \\
0,0042 \text { мекв }\end{array}$ & $\begin{array}{c}6,5 \text { мг/ } \\
0,108 \text { мекв }\end{array}$ \\
\hline $\begin{array}{c}\text { Загальний вміст } \\
\mathrm{Fe}^{3+}\end{array}$ & $\begin{array}{c}1,53 \text { мг/ } \\
0,085 \text { мекв }\end{array}$ & $\begin{array}{c}0,25 \text { мг/ } \\
0,014 \text { мекв }\end{array}$ & $\begin{array}{c}1,89 \text { мг/ } \\
0,105 \text { мекв }\end{array}$ & $\begin{array}{c}0,17 \text { мг/ } \\
0,009 \text { мекв }\end{array}$ & $\begin{array}{c}2,25 \text { мг/ } \\
0,125 \text { мекв }\end{array}$ \\
\hline
\end{tabular}

Примітка: *-визначено автором

У випадку потрапляння у грунт газоконденсатна суміш уповільнює фільтраційні спроможності грунту, що спостеріггалося під час усього експерименту. Рекультиваційні роботи, що проводилися в пробі №5 із метою покращання стану забрудненого грунту, призводять до створення кислого середовища, що корелює із макрокомпонентним складом грунту і може призвести до його засоленості.

Висновки:

1. Основними джерелами забруднення $є$ нафтогазопроводи, газоконденсатна суміш і нафтогазовидобувний комплекс у цілому.

2. Стан газоконденсатних виробництв Полтавської області вимагає постійного моніторингу стану грунтового покриву території. 


\section{СТОРІНКА МОЛОДОГО ВЧЕНОГО}

3. В останні роки відбувається зменшення вмісту гумусу в грунтах Полтавської області. Однією $з$ причин цієї деградації $є$ вплив газоконденсатного комплексу.

4. Потрапляння забруднень спричиняє забивання пор, що призводить до повільної фільтрації грунтового шару.

5. Забруднення нафтогазоконденсаною сумішшю спричиняє зсування водної витяжки грунту в лужний бік, відбувається зміна вмісту і складу органічної речовини, а також якісного складу гумусу.

\section{БІБЛІОГРАФІЯ}

1. Алимов О. М., Даниленко А. І., Трегобчук B. М. Економічний розвиток України: інституціональне та ресурсне забезпечення / О. М. Алимов, А. І. Даниленко. - К. : Об'єднаний інститут економіки НАН України, 2005. - 540 с.

2. Бирюков Н. С. Методическое пособие по определению физико-химических свойств грунтов / Н. С. Бирюков, В. Д. Казарновский, Ю. Л. Мотылёв. - М. : Недра, 1975. - 177 с.

3. ГОСТу 18826-73. Колориметрический метод определения нитратов с сульфосалициловым натрием. - М. : Издательство стандартов, 1974. - 8 с.

4. ГОСТ 4011-72. Вода питьевая. Методы определения общего железа. - М. : Издательство стандартов, 1982. - 9 с.

5. ДСТУ ISO 6059:2003 (ISO 6059-1984, IDT). Визначення сумарного вмісту кальцію та магнію. Титрометричний метод із застосуванням етилендіамінтетраоцтової кислоти. - К., 2004. - 6 с.

6. ДСТУ 10.3.81-6-2001. Якість грунту. Відбір
6. У забруднених пробах грунту відбувається зростання нітрат-іонів, що може спричинити потрапляння їх у водоносні горизонти; збільшення значення водорозчинних солей у забруднених пробах може призвести до засолення грунту, що саме й спостерігається на Полтавщині.

7. Необхідний пошук шляхів локалізації газоконденсатних виливів і відновлення грунтів після газоконденсатних забруднень.

8. Необхідно дослідити можливість використання фіторемедіації для аналізу токсичності грунту і можливості його відновлення.

проб. - К: Держспоживстандарт України, 2002. $-17 \mathrm{c}$.

7. Довжок $С$. . Проблеми розробки нафтових i нафтогазоносних родовищ / Є. М. Довжок, В. С. Іванишин, I. Т. Микитко // Нафтова і газова промисловість. - 2006. - № 3. - С. 26-27.

8. Журнал «Національна безпека і оборона» // Центр Разумкова №2, УЦЕПД. - 2001 p. - 71 с.

9. Звіт про стан навколишнього природного середовища в Полтавській області у 2009 році / Державне управління екології та природних ресурсів в Полтавській області. - Полтава, 2010. $117 \mathrm{c}$.

10. Мазлова E. А. Экологические решения в нефтегазовом комплексе / Е. А. Мазлова, Л. Б. Шагарова. - М., 2001. - 109 с.

11. Шидловський А. К.. Ковалко М. П. Паливно-енергетичний комплекс України на порозі третього тисячоліття. - К., 2001. - 398 с. 